Journal of Law \& Social Studies (JLSS)

Volume 1, Issue 2, pp 61-68, 2019

www.advancelrf.org

\title{
Judicial Activism and Pakistani Society: A Case Study of Musharaf Era
}

\author{
Dr. Muqarrab Akbar \\ Chairman Department of Political Science, \\ Bahauddin Zakariya University Multan, Pakistan. \\ Emai: muqarrabakbar@bzu.edu.pk \\ Mahnoor Malik \\ Visiting Lecturer Department of Political Science \\ Bahauddin Zakariya University Multan, Pakistan. \\ Email: confinement12@yahoo.com
}

\begin{abstract}
Judicial organ is one of the three organs of the state of Pakistan. It plays important role in Constitutional machinery by performing its functions like interpreting laws and keeping an eye over the laws made by legislature that they are according to the injunctions of Islam or not and whether these laws are implemented properly by the executive or not. Judicial activism refers to the judicial rulings based on personal views rather than on existing law. The research is based on the questions like, is Judiciary playing effective role in Pakistan? What is the role of judiciary in Musharaf's regime? Did judicial organ work in accordance with the Constitution of Pakistan 1973 in Musharaf's regime? The conflict between president Musharaf and Chief Justice of Pakistan Iftikhar Chaudhry on March 9, 2007 when the Iftikhar Chaudhry refused to move under the pressure of the former to resign as Chief Justice. This led to the frontal attack by Musharaf against the judiciary on November 3, 2007 in the grab of unconstitutional emergency and PCO. In terms of judicial crisis and lawyers' movement, the resistance offered by a large portion of the judiciary from March 9, 2007 onwards supported by the lawyers' fraternity was a step toward change in favor of an independent judiciary in the future.
\end{abstract}

Keywords: Judicial Activism, Constitution, Pakistan, Media

\section{Introduction}

Judiciary is one of the most important pillars of the state in Pakistan. The judiciary is assigned task "to interpret laws" made by the legislature. Whereas, executive is responsible to implement these laws. Judicial activism means judicial rulings consisted of personal desires or personal views rather than on the already given law particularly when a question regarding public interest arises. The judicial history of Pakistan is encumbered with many historical verdicts in which they validated the executive deeds such as imposition of Martial Laws and PCO. Black's law dictionary explains that judges follow their own personal views to take decisions about the implementation of public policy in all factors (Khan, 2001).

Judicial activism is a very broader term. Judges are supposed to decide the cases in the light of prevailing laws, rules and regulations not on personal views or opinion. Even when a judge adjudicates a matter in his discretion; that basically means he decides the case conclusively within the circle of given law and a judge should be impartial and should decide the cases according to the existing rules, regulations and laws. (Dickson, 2007). 
Judicial history of Pakistan is full of such cases where judiciary was under executive's pressure such as Molvi Tameezud Din's case, in which the appeal of Molvi Tameez-ud Din was dismissed, State vs. Dosso's case, in which the case was decided in the favor of Dosso against state in the light of Doctrine of necessity, and Nusrat Bhutto's case in the favor of non-democratic forces by calling it 'Doctrine of necessity' (Aman Ullah, 2011).

Increasing judicial activism in Pakistan is always criticized by many scholars because for them this overstepping of the judiciary is creating social discord and injustice in the society instead of promoting justice. Although as a third pillar of the state, the Judiciary is assigned task to interpret the laws by examining it whether this law can be made by the legislature constitutionally or not. If the Supreme Court deems a law contradictory to existing laws or contradictory to Islamic teaching, it can be declared as 'ultra vires'. The powers and functions of the three pillars of the state i.e, Judiciary, legislature and Executive have been separated in the 1973 Constitution of Pakistan. So the decision of the judges should also be in the light of existing laws to maintain the separation of power among three pillars of the state in true letter and spirit. However the decisions of judges, if, based on personal opinion as the case in judicial activism, can not only a deviation from the separation of power defined in the 1973 Constitution of Pakistan but also ruin the state administrative system in general and state political system in particular in some cases.

\section{Review of Literature}

Hussain, (2013) opines that when the judges decide the cases on the bases of their personal thoughts, instead of existing law, to resolve issues of public policy or public interest, it is called judicial activism. The excessive use of Suo Moto power by raising the issues of public policy and public interest by the apex court of Pakistan is mantra of the day. The Supreme Court of Pakistan is using the powers of judicial review and Suo Moto excessively in performing its judicial duties. He clearly explains that the judicial activism is completely a deviation from the principle of separation of power given under the 1973 Constitution of Pakistan.

Contrary to Hussian (2013) critical analysis regarding judicial activism, Dahraj, (2010) praises the fear free judicial activism to uphold independence of judiciary to get public trust by dispensation of justice with respect to public policy and public interest. He identifies, it depends on the individual approach and thinking that how much judicial activism is vital in a democratic system. According to him, the doctrine of judicial review is demonstrated through judicial activism. He opines that one of the most important functions of the Apex judiciary of Pakistan is to implement the rules, laws and regulations, in a democratic state, guaranteed by the Constitution of Pakistan. The apex judiciary and subordinate judiciary should work effectively to produce effective results so that the image of judicial activism with special regard to political matters can be minimized and the problems faced in getting this objective should be resolved to make the judiciary more functional as a vital pillar of the state.

Hussain, (2013) criticizes the judicial activism as a problem when judges start to decide the matters of public interests on the basis of personal thoughts and sometimes on the basis of personal perceptions instead of relying on governmental laws, rules and regulations. Defining the existing laws sometimes may lead to amending the existing laws and it is identified as a real threat. The common men sometimes criticize the supreme judiciary on their Suo Moto instead of, might be, its positive side. Political parties in general and the government in particular consider this judicial activism as unnecessary intervention in the administrative affairs of the state.

Ahmed, (2017) explains the proceeding of apex court of Pakistan in case of judicial activism are necessary where executive authority and government fail to fulfill its duties and unable to perform its functions with respect to public interest and public policy. He also explains that judiciary cannot substitute the executive in the matters relating to public interests and public policy rather it can provide guidance to the executive and can overlook the function of the executive to ensure the guarantee of rights to the public given under the 1973 constitution.

\section{Movement for Independence of Judiciary in Pakistan}

The Musharraf- Iftikhar controversy led towards a historic moment in the judicial history of Pakistan. Musharraf asked Iftikhar Choudhary to resign from the post of Chief Justice but the later refused to do so. Hence, Musharraf suspended the Iftikhar Chaudhary and filed a reference of misconduct against him in Supreme Judicial Council. This autocratic and unconstitutional action of Musharraf lead to set up a lawyer's Movement against Perviaz Musharraf. The lawyers of Pakistan started movement against Pervaiz Musharaf's autocratic actions. (Razvi, 2009).

The lawyers' movement was turned into lawyer-military rivalry when, Naveed Akhtar, a lawyer was arrested, probably by the military, without any reason on the start of lawyers' movement. His friends have made unsuccessful attempt to get him out from the problem. Later on, Mian Muhibullah Kakakhel, A senior advocate of Supreme Court of Pakistan 
filed a writ petition in the Peshawar High Court that ordered to release the lawyer from military custody. This decision further aggravated the rivalry between military and lawyers. The lawyers started to protest against the suspension of Iftikhar Chaudhary and urged to reinstate the Iftikhar Chaudhary as Chief Justice of Pakistan by withdrawing all allegations leveled against him in the reference to Supreme Judicial Council filed by the Musharraf regime. The Supreme Judicial Council refused to hear the reference and he was reinstated by a larger bench of the Supreme Court with the help of 'dream team' of lawyers including Tariq Mehmood, Hamid A. Khan, Ali Ahmad Kurd, Munir A. Malik and Aitzaz Ahsan. Presidents of Supreme Court of Pakistan led the lawyers' movement. However, Pervaiz Musharraf, President of Pakistan, imposed emergency and removed the Chief Justice of Pakistan, Iftikhar Chuhdary along with other sixty judges of High Courts and Supreme courts who did not take oath on PCO (Mahmood, 2001).

People from all walks of life joined protest of lawyers' movement for the uplifting of emergency and restoration of judiciary. Meanwhile, Musharraf resigned and Asif Ali Zardari became the president of Pakistan. The political parties particularly the opposition political party PML(N) was instrumental in this lawyers' movement. Finally Chief Justice of Pakistan Iftikhar Chaudhry was restored by Yousaf Raza Gillani, Prime Minister of Pakistan.

\section{Role of media}

Media plays vital role in the lawyers' movement. One of the major reasons that urged media to take side with Political parties and lawyers' movement against military regime was draconian policy of dictatorial regime. Media in general and Geo, one of the mostly viewed channel faced censorship and ban. The offices of Geo were targeted. The role of electronic and print media worked as catalyst in the already charged movement. It is not only the media but civil society, judiciary and common man of Pakistan also played its role in the restoration of judiciary. Print and electronic media was criticized by many officials as they considered that at times they do crossed their authority limits and have created the negative sentiment about the government in public regarding this particular matter. However, the movement was ended up with success by restoration of all judges including Iftikhar Chaoudhary as Chief Justice.

\section{Suo Moto Actions}

It was the time when all civil society, media and opposition political parties were looking towards apex court that emerged as a savior in the result of a mass movement, as their problem solver that can address their grievances against government in public policy realm. Resultantly, a series of Suo Moto actions were taken by the apex court in the public interest and applauded by civil society at large at that time. However, later on, the perception was completely changed as the people are not getting the benefits from this judicial activism as they were expecting. The present research shows that how people of Pakistan see this judicial activism and power of taking Suo Moto by the apex court of Pakistan particularly during Musharraf era and post Musharraf era.

\section{Research Methodology}

This study is based on both qualitative and quantitative methods. The survey was conducted by the researchers to see the perception of people of Pakistan regarding judicial activism. Lawyers, law students, public policy students and people with different professions were target population for sampling. Mostly respondents are associated with legal profession so that their opinion can be considered important as the matter in question is pertaining to the law and society. A survey has been conducted from 300 respondents for this research. The researchers have visited the courts, law colleges and public policy departments to collect the data. Questionnaire has been personally developed by the researchers. The collected data has been analyzed on Statistical tool, SPSS. All the results are personally generated and calculated by the researchers. The tables are given below

\section{Gender of Respondents (Table 1)}

\begin{tabular}{|l|c|l|}
\hline Gender & Frequency & $\%$ \\
\hline Female & 115 & $38 \%$ \\
\hline Male & 185 & $62 \%$ \\
\hline Total & 300 & $100 \%$ \\
\hline
\end{tabular}


AGE of Respondents (Table 2)

\begin{tabular}{|l|l|l|}
\hline Age group & Frequency & $\%$ \\
\hline $20-35$ & 160 & $53 \%$ \\
\hline $35-50$ & 90 & $30 \%$ \\
\hline 50 above & 50 & $17 \%$ \\
\hline Total & 300 & 100 \\
\hline
\end{tabular}

\begin{tabular}{|c|c|c|c|c|c|c|}
\hline Sr. \#. & Statement & S.A(1) & $\mathbf{A}(2)$ & $\mathbf{U}(\mathbf{3})$ & $\mathbf{D}(4)$ & S.D $(5)$ \\
\hline 1. & $\begin{array}{l}\text { The Judiciary is performing its functions properly in } \\
\text { Pakistan. }\end{array}$ & $2 \%$ & $3 \%$ & $0 \%$ & $80 \%$ & $15 \%$ \\
\hline 2. & $\begin{array}{l}\text { The Judicial Activism is helpful in resolving problems } \\
\text { in Pakistan. }\end{array}$ & $5 \%$ & $7 \%$ & $0 \%$ & $80 \%$ & $8 \%$ \\
\hline 3. & $\begin{array}{l}\text { The Judiciary is more active during democratic } \\
\text { regime in Pakistan. }\end{array}$ & $5 \%$ & $10 \%$ & $6 \%$ & $77 \%$ & $3 \%$ \\
\hline 4. & $\begin{array}{l}\text { The Judiciary is more active during dictatorship } \\
\text { regime. }\end{array}$ & $62 \%$ & $20 \%$ & $6 \%$ & $5 \%$ & $7 \%$ \\
\hline 5. & $\begin{array}{l}\text { Media has played its role in Judicial activism during } \\
\text { Musharaf regime. }\end{array}$ & $5 \%$ & $86 \%$ & $3 \%$ & $4 \%$ & $2 \%$ \\
\hline 6. & $\begin{array}{l}\text { Media has played its vital role in restoration of judges } \\
\text { during Musharaf regime. }\end{array}$ & $12 \%$ & $80 \%$ & $2 \%$ & $6 \%$ & $0 \%$ \\
\hline 7. & Judicial activism is useful for social change. & $5 \%$ & $15 \%$ & $5 \%$ & $72 \%$ & $3 \%$ \\
\hline 8. & $\begin{array}{l}\text { Judges of Higher Courts tend to make laws rather than } \\
\text { interpret them in Pakistan. }\end{array}$ & $64 \%$ & $22 \%$ & $8 \%$ & $6 \%$ & $0 \%$ \\
\hline 9. & $\begin{array}{l}\text { Some judges misused their constitutional power in } \\
\text { Pakistan during Musharaf regime. }\end{array}$ & $9 \%$ & $79 \%$ & $5 \%$ & $5 \%$ & $2 \%$ \\
\hline 10. & $\begin{array}{l}\text { Judges are using their discretionary power in } \\
\text { accordance with law while deciding the cases. }\end{array}$ & $3 \%$ & $89 \%$ & $5 \%$ & $3 \%$ & $3 \%$ \\
\hline 11. & $\begin{array}{l}\text { Judicial activism made Justice Iftikhar Chaudhary a } \\
\text { disputed personality during Musharaf era. }\end{array}$ & $67 \%$ & $22 \%$ & $3 \%$ & $5 \%$ & $3 \%$ \\
\hline 12. & $\begin{array}{l}\text { Judiciary is interfering the other organs of the state } \\
\text { since the Independence of Pakistan. }\end{array}$ & $12 \%$ & $82 \%$ & $0 \%$ & $6 \%$ & $0 \%$ \\
\hline 13. & $\begin{array}{l}\text { The lawyers' movement gave the judiciary a feeling of } \\
\text { independence in Musharaf regime. }\end{array}$ & $5 \%$ & $89 \%$ & $2 \%$ & $3 \%$ & $1 \%$ \\
\hline
\end{tabular}




\begin{tabular}{|c|c|c|c|c|c|c|}
\hline 14. & Judicial activism is essential to correct injustices. & $8 \%$ & $12 \%$ & $5 \%$ & $72 \%$ & $3 \%$ \\
\hline 15. & $\begin{array}{l}\text { During Musharaf's regime protest of lawyers is for the } \\
\text { pursuance of their personal interests. }\end{array}$ & $2 \%$ & $86 \%$ & $2 \%$ & $8 \%$ & $2 \%$ \\
\hline
\end{tabular}

\section{Findings:}

- This research is evaluated on the measurement scale from one to five and then evaluated on the Likert scale. Here 5 is strongly disagree, 4 Disagree, 3 neutral, 2 agree and 1 strongly agree.

- In response to a statement about the functioning of judiciary an overwhelming majority $95 \%$ is of the opinion that Judiciary in Pakistan is not performing its functions properly. This feedback shows that the judicial department is not pursuing its duties effectively and eventually it becomes the cause of bringing judicial activism in Pakistan where judges adjudge the cases on their personal requirements rather than on presented laws.

- In response to a statement about effectiveness of the judicial activism, overwhelming majority of $88 \%$ is of the opinion that Judicial Activism is not helpful in resolving the problems of Pakistan. The result shows a clear picture that a large number of people agreed that judicial activism is not addressing real problems of the society.

- In response to a statement about the activeness of the judiciary during democratic regime, $80 \%$ opines that judiciary remains less active in democratic rule as compare to dictatorial rule and it may is due to democratic system and respect of public opinion.

- While answering about activeness of judiciary, $80 \%$ of the respondents are of the opinion that judiciary is more active in dictatorship rule. Hence, it may lead to judicial activism because of one man rule who does not respect public opinion and in such environment, the judicial organ becomes active.

- $\quad 91 \%$ respondents are of the opinion that media played a major role in promotion of judicial activism during Musharaf regime. Media was backed by many political leaders from prominent political parties. Media in Pakistan always faced censorship during dictatorial regime so their natural alliance has always been with democracy.

- In the survey, an overwhelming majority of $92 \%$ agree that media is one of the major players that played its role in the restoration of judges.

- The result shows that $75 \%$ disagree that judicial activism is useful for social change. Majority is of the opinion that Judicial activism has more demerits than its merits because basically judicial activism, in the end, resulted not beneficial for the common man and it is assumed that it is based on personal motives by the judges rather than on enacted laws. Eventually it would not be helpful for social change.

- The judicial organ is one of the vital organs of the state of Pakistan and its duty is to have check on the laws made by the legislature this survey shows that judiciary instead of performing its functions of interpreting laws as per assigned task according to the constitution, it is interfering in other two organs' functions. $86 \%$ responded consider that judges are inclined to make new laws instead of interpreting the existing by judicial activism.

- The survey shows that $88 \%$ people think that some judges misused their constitutional power during Musharaf regime.

- The research shows that a large number of people, $92 \%$, agree that judges are deciding the matters by using discretionary powers and this power does not mean to decide matters according to one's own choice but according to the circumstances and situation of the case and moreover within the ambit of law.

- Although Justice Iftikhar was restored in result of lawyers' movement yet, as per opinion of 89\%, he became controversial personality in post restoration movement due to one or other reason

- Judiciary is an important pillar of state and can work on the principle of separation of power or balance of power. However, 94\% people believe that Judiciary is interfering in the other organs of the state since independence of Pakistan.

- It is indeed a difficult to stand against the decisions of dictatorial regimes but lawyers played vital role in this resistance movement. The results of the survey also confirms that as $94 \%$ people agree that feeling of independence in judiciary during Musharraf regime was an outcome of the lawyers' movement. 
- Normally judicial activism can be seen as a way to address the real issues and maintain justice among the society. However, in case of Pakistan, an overwhelming majority of $75 \%$ people think vice versa and believe that Judicial activism is not essential to correct injustice. It is due to the reason that judicial activism in Pakistan does not bring any justice in the society at large.

- The post restoration of judgjes also reveals that the lawyers' protest was for personal interest not for national interest. The $88 \%$ respondents have this point of view as per survey of the researchers.

\section{Conclusion}

It can be concluded from the survey that the judiciary is not functioning properly in Pakistan. During dictatorial regime, it has been more active whereas in democratic regime, its role is passive. The appointment of Justice Iftikhar Muhammad Chaudhry as Chief Justice of Pakistan, in 2005, made judiciary more active as he started exercising the powers of Suo Moto judicial review. The judicial activism urged President Musharaf to think about a Constitutional amendment that will take the power of judicial review and Suo Moto from the apex court. Because as a dictator, he wanted to grab unlimited power to control the state so that no one could stop him in making the state according to his own vision. The historical events shows that judiciary always supported the military coup, hence apex court is closely associated with the military and the nexus between the two always created hurdle in effective and continuous working of democracy in Pakistan. The confrontation with Supreme Court in general and with Chief Justice in particular became a major reason of his fall. It was a part of power play between President Musharaf and Chief Justice of Pakistan in 2007 over Musharaf's attempt to get an extraordinary prolonged mandate as his predecessors had also done but CJP would not support. The overwhelming support among masses gave undue strength to Iftikhar Chouhdary as Chief Justice of Pakistan and started to address multiple issues of public interests without realizing that it would be too difficult to handle multiple complex issues simultaneously. In some cases he was successful whereas some resulted into a failed attempt without any proper conclusion or decision. Hence, it can be concluded that judicial activism has both pros and cons that depends upon its proper implementation. The Constitution of Pakistan clearly defines the principle of separation of powers among three pillars of the state i.e. legislature, executive and judiciary. However, there is no separation of power exist in these institutions of the state. These three institutions remained always curious in getting more power in power game. However the role of military establishment cannot be neglected in the context of Pakistan as in past, in many cases, it was the apex judiciary that validated the unconstitutional steps. Moreover, it can also be concluded that the powers of Suo Moto and judicial review are given to the Supreme Court to maintain the check and balance system of governance and to guarantee the fundamental rights to the citizens of Pakistan. These powers should be used only in extraordinary state of affairs where there is a question of survival of the state is at stake instead of using it excessively.

\section{References}

Ahmed Sami, (2013), The Judiciary of Pakistan and its role in Political Crisis, Royal book company Karachi.

Ahmed Noman, (2017), “Governance through Judiciary “DAWN NEWS.

Akhtar Asim Sajjad, (2017),“Musharaf’s Legacy” DAWN NEWS

Aman Ullah, (2011), Judicial Activism and Human Rights in Pakistan and India: Right to Life, Germany

Amir Ayaz, (2013), "Musharaf and the Media" THE NEWS.

Asad Malik, (2018), “Over 1.8 million cases pending in Pakistan's courts” DAWN

Ashraf Ahmed, (2013), “Nation does not need Judicial imperialism” DAWN NEWS.

Ashraf Muhammad Malik, (2017) "Fourth pillar of the state" THE NATION.

Azeem Muhammad, (2017), Law, State and inequality in Pakistan, Platinum Publishing Limited, London, 2000 and Pakistan Law House, Karachi, 2000

Barton David, (2007), Restraining Judicial Activism, Columbia University Press 
Berger Raoul, (1977), Government by Judiciary, Liberty Fund press. Pg 340-400

Bybee Keith, (2010), All Judges are Political-except When they are Not Stanford University Press. Pg 110-150

Cowe Justin, (2012), Building the Judiciary: Law, Courts and Politics of Institutional Development, Princeton University Press. Pg 132-210

Dickson Brice, (2007), Judicial Activism in Common Law Supreme Courts, Oxford University Press

Faisal Siddiqi, (2016), “Judicial Accountability” DAWN NEWSPAPER.

Faisal ul Islam, (2017) Judicial Activism essays

Griffith John Aneurin Grey, (1977), The Politics of the Judiciary, Fontana Press. Pg 150-180

Haider Menahil, (2016), “Judicial Activism or Adventurism “DAWN NEWS.

Harwood Sterling, (1996), Judicial Activism: A Restrained Defense, San Francisco, CA: Austin and Winfield, 1996

Hussain Faisal, (2013), “Outcome of Judicial Activism” DAWN NEWS.

Hussain Irfan, (2017), “Judicial Freedom” DAWN NEWS.

Jaffrelot Christophe, (2016), Pakistan at the crossroads domestic dynamics and external pressures, Columbia University Press

Katzmann Robert, (2014), Judging Statutes, oxford University Press. Pg 162-170

Kayani Yasir, (2015), “ For an Independent Judiciary “DAWN NEWS.

Khan Hamid, (2001), Constitutional and Political History of Pakistan $2^{\text {nd }}$ Edition, oxford University Press

Khan Hamid, (2016), A history of Judiciary in Pakistan, Oxford University Press

Khan Shabbier Ahmed, (2012), “Judicial Independence "PAKISTAN TIMES.

Khan Shuaib, (2012), “Judicial Activism "DAWN NEWS.

Khosa Sameer, (2018) “Judicial Reform” DAWN

Larsen Orr Allison, (2010), The Pakistani Lawyers' movement and the popular Currency of Judicial Power, Harvard Law Review 123, 7

Lokhandwala Zainab, (2013), "Pakistan's struggle for an independent judiciary” DAWN NEWS.

Lowe David, Das .K Dilip (2017), Trends in Judiciary: Interviews with judges across the Globe, Vol 3, Taylor and Francis Press. Pg 90-100

Malik Basil Nabi, (2013), “Independent Judiciary” DAWN NEWS.

Malik Hussain Tufail, (2016) “Justice System” DAWN

Naureen Adeela, (2018) “Judicial Reform and ground reality” THE NATION

Nawaz Ali Dahraj, (2010), “Judicial Activism and Social Justice” DAWN NEWS. 
O’Brien M. David, (1997), Judges on Judging: Views from the Bench, CQ Press. Pg 250-350

Omer Reema, (2016), “Year of Judicial Accountability” DAWN NEWS.

Posner Richard, (2010), How Judges Think, Harvard University Press.Pg 230-290

Qaiser Ali, (2011), “Judicial Activism in Pakistan "DAWN NEWS.

Rashid Qaiser, (2018) “Judicial Activism” DAILY TIMES

Reayat Nauman, Mujahid ul Anwar, Mujahid ul Saif, (2015) Politics of Judicial Activism and good governance in Pakistan, Lambert Academic Publishing

Rizvi Arshad Javed, (2016), “Judicial Reforms” DAWN NEWS.

Roosvelt Kermit, (2006), The myth of Judicial Activism, Yale University Press

Sattar Babar, (2014), “Who will save the Justice System?” DAWN NEWS.

Sherry Suzanna, Farber A. Daniel, (2008), Judgment Calls: Principle and Politics in Constitutional Law, Oxford University Press. Pg 100-201

Soomro Zahid Iqbal, (2009), “Musharaf versus Freedom of Media” DAWN NEWS.

Toobin Jeffrey, (2001), Too close to Call, Random House Publishing Group. Pg 95-200

Unknown, (2008), "PCO and its victim Judges” DAWN NEWS

Unknown, (2011), “Judges took oath under PCO to save system: Counsel” DAWN NEWS.

Unknown, (2018) “Reforming Justice” DAWN

Waseem Mohammad, (2009), "Impact of Army on the Judiciary "DAWN NEWS.

Wilkinson Kambard, (2007), “Crisis for Musharaf over Justice Chief's sacking,” THE NEWS

Zaidi Hussain, (2010), "When Judicial Activism is warranted "DAWN NEWS.

Zelden L.Charles, (2007), The Judicial branch of Federal Government: People, Process and Politics, ABC-CLIO Press. Pg 290-330 